ENGAGED DHAMMA AND TRANSFORMATION OF DALITS- AN EGALITARIAN EQUATION IN INDIA TODAY (Engaged Buddhism And The Impact Of Buddhist Philosophy In Transforming Our Social World In Terms Of Egalitarianism And Social Justice)

\author{
Dr. Preeti Oza
}

St. Andrew"s College

University of Mumbai

\begin{abstract}
Engaged Buddhism refers to Buddhists who are seeking ways to apply the insights from meditation practice and dharma teachings to situations of social, political, environmental, and economic suffering and injustice.

The Non-duality of Personal and Social Practice is making such engagement possible even today. Buddhist teachings themselves as the restrictive social conditions within which Asian Buddhism has had to function. To survive in the often ruthless world of kings and emperors, Buddhism needed to emphasize its otherworldliness. This encouraged Buddhist institutions and Buddhist teachings (especially regarding karma and merit) to develop in ways that did not question the social order. In India today, Modern democracy and respect for human rights, however imperfectly realized, offer new opportunities for understanding the broader implications of Buddhist teachings. Furthermore, while it is true that the post/modern world is quite different from the Buddha"s, Buddhism is thriving today because its basic principles remain just as true as when the Buddha taught them.

A classic case of engaged Buddhism in India is discussed in this paper which deliberates on the Dalit- Buddhist equation in modern India. For Dalits, whose material circumstances were completely different from the higher castes, the motivation continually remained: to find out concerning suffering and to achieve its finish, in every person"s life and in society. Several of them have turned to Dhamma in response to the Buddha"s central message concerning suffering and therefore the finish of suffering.

Previously lower-caste Hindus, the Indian Buddhists in Nagpur regenerate under the political influence of Babasaheb Ambedkar, the author of India"s constitution, to denounce caste oppression. They became Buddhist for political and religious reasons, and today, the implications of their actions still unfold in some ways. Their belief in the four seals of Buddhism-

- All physical things are impermanent,

- All emotions are the reasons for pain,

- All things don't have any inherent existence and

- Nirvana is the moderation in life,
\end{abstract}

Have created them renounce the atrocities and injustice of Hindu savarnas that were carried on since last several centuries.

\title{
INTRODUCTION
}

Today the term „Buddhism" means a religion of introspective withdrawal or religion to attain Nirvana and Moksha, as believed by many people in the West. But the reality of contemporary „Asian Buddhism, is very different. Buddhism in contemporary Asia nowadays means a very energetic engagement which sometimes converts into a movement with social and political issues, which is not ending into any monastic or meditative withdrawal. Throughout Asia, Buddhist monks and nuns have brought many institutional and social changes and on the international level, the contribution of Buddhists, to the conceptualization and implementation of nonviolent action for the establishment of peace for Social Justice have been so great that two recent Nobel Peace Prizes have gone to two Buddhist leaders- the Dalai Lama of Tibet and Aung San Suu Kyi of Myanmar

The concept of engaged Buddhism, from Thich That Hang to Daisaku Ikeda to Dr. Ambedkar- has been consistently advocating for the activists of world peace in their own specific manner. The unprecedented awarding of Nobel Peace Prizes to two Buddhists in a three year period, and the prevalence of the theme of "inner peace and world peace", suggest this as a distinguishing mark of contemporary engaged Buddhism. The tone and style of Buddhist activism do not always match the stereotype of the mild and selfeffacing Monk. Indeed the tensed arms and clenched fist of a robbed Monk addressing a public gathering in Sri Lanka makes a striking cover for Thambiah"s Buddhism betrayed?, While Ambedkar"s slogan "Educate. Agitate ... Organize" sounds unlikely as an update of the Ancient Buddhist precepts 
DR. AMBEDKAR AND ENGAGED BUDDHISM

The movement founded a half-century ago by Dr. Ambedkar is a new wave of Buddhism which is helping the Dalits who were previously called „untouchables" in India, to adopt a respectable life, which their own religion is not able to give them since ages. Dr. Ambedkar, who was the Columbia Universityeducated lawyer and who has played a key role in drafting independent India's Constitution, was a born Dalit and after his very serious research on many religions, he saw the Buddha as a radical social reformer who created an outlet from the rigid Hindu caste system.

In 1954, when Dr. Ambedkar converted to Buddhism along with his thousands of the loyal supporters, as a protest against the discriminatory practices of Hindu religion towards the untouchable"s orderlies, he wrote a Blueprint for the spread of Indian Buddhism which was a new wave of engaged Buddhism. According to this Blueprint of Indian Buddhism, Dr. Ambedkar has recommended printing of a very compact Buddhist Gospel in a small booklet, like the Bible, and also created a ceremony like a Baptism for the newly established Buddhists who changed the religion from Hinduism to Buddhism. The very first Buddhist Society of India was founded by him in 1955 and showed an enlightened path to many of his followers, who have been embracing Buddhism since last 70 years in India.

As per the latest census in India (http://censusindia.gov.in/), the number of registered Indian Buddhists or the Neo Buddhist is almost 8.4 million and out of them about $87 \%$ are Ambedkarite, those who have accepted and embraced Buddhism but were born Hindus, and the rest are ethnic Buddhists in the Himalayan provinces or Tibetan refugees who followed the Dalai Lama to India.

In the current socio-political situation in India, Ambedkarite Buddhism or the new Buddhism is becoming an increasingly popular option for marginalized and un-satisfied Dalits across India because converting from Hinduism to Islam or Christianity is now legally not valid in several States. Buddhism even today is considered a subset of Hinduism in Article 25 of the Indian constitution, and which is useful for these Neo Buddhist who are born Hindus to call themselves Buddhists. And to support the mainstream Hindu version over the course of Indian history, Buddhism has been on easily absorbed into the Hindu mainstream religion. There are many minutes and scriptural stories where Buddha is described as an incarnation of the Hindu God Vishnu, though the newly converted Ambedkarite Buddhists are seriously contesting this notion.

As a Mass Social Movement, this „engaged" form of Dhamma is having its focus on caste-based inequality. To support this notion, Ambedkarite Buddhists share concerns of the historical Buddha who was a prince and who has rejected the Hindu caste, the Vedas, and the Vedic rituals during his philosophical journey which has finally led him to the peak of his enlightenment. But this School of Buddhists believer is different from the mainstream Buddhist schools like Theravada and Mahayana. These two mainstream Buddhist schools which are popular over the last two millennia are categorically dismissed by Ambedkarite Buddhism. This domain shift has come from the four noble truths to meditation, to the doctrine of rebirth, calling them non-Canonical streams and they believe that it has come into practice after the Buddha's lifetime. So the contemporary Ambedkarite institutions across India and abroad focus more on the engaged Dhamma which is also called the socially active form of Buddhism.

When Dr. Ambedkar, in 193, decided to leave Hinduism and embraced Buddhism, told a gathering of 10,000 people that I will not die a Hindu. His only desperate hope in this step was that Hinduism could be rid of untouchability in the caste system itself and that supported the Reformist initiatives including the Temple Entry Movements. Zelliot in her studies states that "Ambedkar"s own decision to convert seems to have been made on the intellectual and emotional Grounds, a stab at the religion, which denied him equality and self- respect". ( Zilliot 1972). The Spiritual dimensions of India's Dalit Buddhist movement, as explained by Loritta Ying Ping Chan, despite the movement"s name and the Buddhist philosophy, is of insurable love which is embraced, the movement was not a revival of Buddhism for it lean towards social-political reforms and less so on religious faith. (Chan 2015).

\section{A NEW PHENOMENON}

All the movements pertaining to the engaged Buddhism have a specific but at the same time a popular leader or leaders whose identity and mission are understood by followers to be distinctly Buddhist. The best example in this respect is that of the Dalai Lama who is venerated as an incarnation of the Holy Bodhisattva Avalokiteshvara -The Patron Saint of Tibet and the Epithelium of divine compassion. Throughout the world, followers of Tibetan tradition show respect for Dalai Lama by displaying his photograph on the walls across their homes.

A similar phenomenon is observed in the years since Dr. Ambedkar"s death. There is a rise in a devotional Cult among his followers to display his image in their homes or outdoors in the form of stone or bronze monuments. But another interesting and significant comparison is that, in both instances one old (the Dalai Lama has long been venerated as symbols of Wisdom and Compassion by Tibetan Buddhists) and one new (never before any Indian untouchable individual been venerated as a Buddhist leader or 
Monk) is that the images of incumbent or juxtaposed with that of the Buddha and it is found not in the temple but in the home or on the street corner.

Dr. Ambedkar"s Magnum Opus, The Buddha, and his Dhamma, was written in English and the style imitates that of the English orientalist. For its prologue, Ambedkar shows a paragraph from James Hastings Encyclopaedia of religion and ethics (1908), in which the modern revival of interest in religion "as a subject of critical and scientific inquiry" is explained by the rise of scientific knowledge, the inherent intellectual interest of religion, worldwide tendency to form and reconstruct religion along more rational and scientific, and less superstitious lines. (Ambedkar, 2011)

Dr. Ambedkar, as a member of India's first cabinet, proposed the use of the Buddhist Dharma Chakra or the Wheel of the Law on the new flag of India and the Ashokan Lion-Capital on the national currency. Another expression of Ambedkar"s affinity for Buddhist symbols, as in case of the engaged Buddhism, was his naming of the colleges he founded under the People's Education Society. With the provision of government subsidized educational opportunities for the lower classes, Siddharth College in Mumbai named for the Buddha and Milind College in Aurangabad named for Buddhism first Western convert, reflect as much the pragmatism and progressivism.

\section{REDEFINING RELIGION, DHAMMA, AND ACTIVISM:}

With Ambedkar's nonagreement and frustration towards the caste equation in India, it is important to know why he chose Buddhism. According to Gauri Viswanathan, it was due to the spiritual impoverishment of primary Hinduism which produced not metaphysical despair but a profound sense of injustice, Ambedkar clearly saw as the heart of the Buddhist conversion experience. (Vishwanathan 1996).

"There is a social aspect to Ambedkarite Buddhism," said Mangesh Dahiwale, a veteran Dalit rights activist in Pune. "It"s not just an emancipatory path for individuals. We think it doesn"t make sense for you to become Buddhist alone when your society is downtrodden," he said. ( Immerwahr 2008) This contrasts with Buddhism"s popular consumption in the West, which is often oriented around individualist concepts like personal fulfillment and peace of mind.

\section{REFERENCES:}

Ambedkar, Bhimrao Ramji. The Buddha and his dhamma: A critical edition. Oxford University Press, 2011.

https://indianexpress.com/article/explained/why-buddhism-invites-dalits-300-dalits- convert-to-buddhismin-gujarats-una-5157770/

Immerwahr, Daniel. "On BR Ambedkar and Black-Dalit Connections." (2008).

Loritta Ying Ping Chan: The Spiritual Dimension of India's Dalit Buddhist Movement: The Untouchables' Self-Renewal, Department of Asian Languages and Culture, University of Michigan 2015

Queen, Christopher S. "Introduction: The shapes and sources of engaged Buddhism." Engaged Buddhism: Buddhist Liberation Movements in Asia (1996): 1- 44.

Queen, Christopher S., Charles S. Prebish, and Damien Keown, eds. Action Dharma: new studies in engaged Buddhism. Vol. 23. Psychology Press, 2003.

Viswanathan, Gauri. "Religious conversion and the politics of dissent." Conversion to Modernities: The Globalization of Christianity (1996): 89-114.

Zelliot, Eleanor. "Gandhi and Ambedkar: A study in leadership." The untouchables in contemporary India (1972): 69-95. 